\title{
PENINGKATAN KOMPETENSI DASAR MATA PELAJARAN AGAMA ISLAM SEKOLAH DASAR HANG TUAH V JAKARTA MELALUI STRATEGI PEMBELAJARAN ACTIVE LEARNING
}

\author{
Syarifah Hanum
}

\begin{abstract}
The purpose of this research was to know the improvement of basic competency of Islamic Religion Subject through active learning strategy. This research was held in the second year of Hang Tuah V Elementary School Jakarta, in the second semester, 2007/2008 academic year. The design of this research involved 4 steps: (1) planning, (2) acting, (3) observing, and (4) reflecting. The result of this research was that there was an increase between the means of first cycle and of the second one, 67 and 81 respectively. Furthermore, most of active learning aspects observed progressed between the first cycle and the second one, $64 \%$ and $80 \%$ respectively. It can be concluded that application of active learning strategy in Islamic Religion Subject can improve the competencies of students in the second year of Hang Tuah V elementary school in Jakarta.
\end{abstract}

Keywords :basic competency, active learning strategy, instructional model, learning achievement.

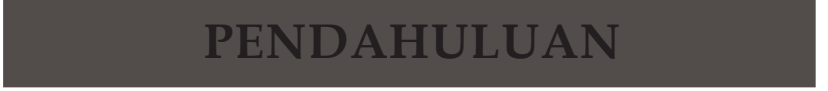

Mata pelajaran Agama Islam merupakan pelajaran wajib di semua jenjang pendidikan di Indonesia. Semua siswa wajib mengikuti pelajaran agama dengan standar nilai kelulusan minimal enam. Pelajaran agama bukanlah pelajaran yang menjadi favorit bagi siswa karena pembelajaran agama di sekolah cenderung masih diajarkan secara konvensional, siswa pasif, dominan ceramah, materi normatif dan abstrak, serta penjelasan pelajaran agama belum diintegrasikan dengan perkembangan ilmu pengetahuan dan teknologi (IPTEK).

Rendahnya kemampuan guru agama dalam pengelolaan kelas yang cenderung tidak pandai membangkitkan kreativitas dan aktivitas siswa sering menjadi penyebab kurang menariknya pelajaran agama islam di sekolah. Sebagaimana yang banyak dikeluhkan bahwa guru-guru Agama Islam memiliki kemampuan yang kurang dalam pengelolaan kelas melalui active learning sehingga pembelajaran tampak monoton dan menjenuhkan.

Semua keluhan tersebut merupakan masukan yang sangat berharga bagi guru-guru Agama Islam untuk segera mencarikan penyelesaiannya, yakni dengan jalan meningkatkan strategi pembelajaran pada mata pelajaran Agama Islam. Oleh karena itu, penelitian tindakan ini dilakukan untuk mengamati dan mengembangkan serta memperbaiki strategi pembelajaran yang dipergunakan guru Agama Islam dalam usaha meningkatkan kompetensi dasar mata pelajaran Agama Islam bagi siswa-siswa Sekolah Dasar Hang Tuah V Jakarta.
Adapun perumusan masalah dalam penelitian ini adalah

1. Bagaimana strategi pembelajaran active learning diterapkan pada mata pelajaran Agama Islam di SD Hang Tuah V Jakarta?

2. Setelah guru menerapkan strategi pembelajaran active learning dalam pembelajaran mata pelajaran Agama Islam, apakah siswa-siswa SD Hang Tuah V Jakarta meningkat kompetensi dasarnya dalam bidang Agama Islam?

\section{Active learning}

Active learning atau belajar aktif adalah teknik pembelajaran yang mengembangkan potensi berpikir. Ide active learning ini dilatarbelakangi oleh adanya pemikiran bahwa tidak semua yang diceramahkan oleh guru itu dapat diingat semua oleh siswa, namun hanya sebagian kecil saja yang mengingatnya karena adanya perbedaan kecepatan kemampuan siswa dalam mendengarkan pelajaran dari guru. Oleh karena itu, jika ingin banyak yang diingat siswa sebaiknya menggunakan metode lain yang lebih mengajak keterlibatan siswa (Silberman, 2001).

Penelitian menunjukkan bahwa siswa mendengarkan (tanpa berpikir) rata-rata 400-500 kata per menit. Ketika mendengarkan secara terus menerus selama waktu tertentu pada seorang guru yang sedang bicara empat kali lebih lambat, siswa cenderung bosan dan pikiran mereka akan melayang kemana-mana (Johnson dan Smith, 1991 dalam Silberman, 2001). Penelitian Pike (1989) menunjukkan bahwa dengan 
menambahkan visual pada pelajaran akan menaikkan ingatan dari $14 \%$ ke 38\%. Penelitian ini juga menunjukkan perbaikan sampai 200\% ketika kosakata diajarkan dengan menggunakan alat visual. Bahkan waktu yang diperlukan untuk menyampaikan konsep berkurang sampai 40\% ketika visual digunakan untuk menambah presentasi verbal. Sebuah gambar barangkali tidak bernilai ribuan kata, namun tiga kali lebih efektif daripada hanya kata-kata saja.

Manakala pengajaran menggunakan auditorial dan visual, kesan menjadi lebih kuat dengan sistem penyampaian itu. Otak seseorang tidak berfungsi seperti audio recorder atau tape recorder, begitu informasi masuk langsung dapat dijalankan. Otak tidak hanya menerima informasi tetapi juga memprosesnya sebagaimana komputer. Ketika belajar secara pasif, otak tidak "hidup". Sebuah komputer memerlukan software yang tepat untuk menafsirkan data-data yang dimasukkan. Otak perlu dihubungkan dengan apa yang diajarkan, dengan apa yang telah diketahui, dan bagaimana berpikir. Ketika belajar secara pasif, otak melakukan hubungan ini pada software. Akhirnya, sebuah komputer tidak dapat menyimpan informasi yang telah diproses tanpa "menyimpannya". Otak perlu mempertanyakan informasi, merumuskan atau menjelaskannya pada orang lain agar dapat menyimpannya dalam memori. Ketika belajar secara pasif, otak tidak menyimpan apa yang telah dipresentasikan.

Ada banyak hal yang dapat diajarkan, bukan diberitahukan. Belajar bukan merupakan konsekuensi otomatis dari penyampaian informasi ke dalam kepala seorang peserta didik. Belajar membutuhkan keterlibatan mental dan tindakan pelajar itu sendiri. Itulah yang disebut cara belajar aktif. Mereka menggunakan otak sendiri, mempelajari gagasan, memecahkan berbagai masalah, dan menerapkan apa yang mereka pelajari. Belajar aktif merupakan langkah cepat, menyenangkan, mendukung, dan secara pribadi menarik hati. Seringkali, peserta didik tidak hanya terpaku di tempat-tempat duduk mereka, tetapi berpindah-pindah dan berpikir keras.

Belajar yang sesungguhnya tidak akan terjadi, tanpa ada kesempatan untuk berdiskusi, membuat pertanyaan, mempraktikkan, bahkan mengajarkan pada orang lain. Oleh karena itu, Holt (1967) (dalam Silberman, 2004), mengemukakan bahwa belajar akan semakin baik jika siswa diminta untuk melakukan halhal, sebagai berikut.

1. Mengungkapkan informasi dengan bahasa mereka sendiri.

2. Memberikan contoh-contoh.
3. Mengenalnya dalam berbagai samaran dan kondisi.

4. Melihat hubungan antara satu fakta atau gagasan dengan yang lain.

5. Menggunakannya dengan berbagai cara.

6. Memperkirakan beberapa konsekuensinya.

7. Mengungkapkan lawan atau kebalikannya.

Belajar aktif merupakan sebuah kesatuan sumber kumpulan strategi pembelajaran yang komprehensif. Belajar aktif meliputi berbagai cara untuk membuat peserta didik aktif sejak dari awal melalui aktivitas-aktivitas yang membangun kerja kelompok dan dalam waktu singkat membuat mereka berpikir tentang materi pelajaran. Juga terdapat teknik-teknik memimpin belajar bagi seluruh kelas, bagi kelompok kecil, merangsang diskusi dan debat, mempraktikkan keterampilan-keterampilan, mendorong adanya pertanyaan-pertanyaan, bahkan membuat peserta didik dapat saling mengajar satu sama lain.

Untuk membuat peserta didik aktif sejak dini, dilakukan teknik-teknik pembelajaran, antara lain.

(1) Team building (untuk menciptakan semangat kerja sama).

(2) On-the-spot assessment (untuk menilai dan mempelajari perilaku, pengetahuan, dan pengalaman siswa).

(3) Immediate learning involvement (untuk menciptakan minat awal dalam pokok bahasan).

Teknik pembelajaran yang digunakan untuk membantu peserta didik agar tetap belajar aktif di tengah-tengah pelajaran, antara lain.

(1) Full-class learning (petunjuk dari pengajar yang merangsang seluruh kelas).

(2) Class discussion (dialog mengenai pokok bahasan utama).

(3) Question prompting (cepatnya siswa minta penjelasan).

(4) Collaborative learning (belajar dengan bekerja sama).

(5) Peer teaching (belajar dengan sebaya).

(6) Independent learning (belajar mandiri).

(7) Affective learning (belajar afektif).

(8) Skill development (pengembangan keterampilan).

Untuk membuat belajar tidak mudah lupa, perlu dirancang teknik pembelajaran, yaitu.

(1) Review (pengulangan).

(2) Self-assessment (penilaian diri sendiri).

(3) Future planning (perencanaan masa yang akan datang).

(4) Expression of final sentiments (mengomunikasikan pikiran dan perasaan).

(5) Perhatian siswa yang mereka miliki pada akhir kelas. 


\section{Strategi Pembelajaran}

Strategi pembelajaran merupakan urutan atau langkah pembelajaran untuk mencapai tujuan pembelajaran yang telah ditetapkan (Kemp dan Morison, 1994). Oleh karena itu, penentuan strategi pembelajaran didasarkan atas pendalaman terhadap dimensi psikologis tujuan pembelajaran, seperti fakta, konsep, prinsip, prosedur, sikap, dan pemecahan masalah.

Strategi pembelajaran menurut Dick dan Carey (1990) memuat lima komponen utama, yaitu.

1) Aktivitas preinstruksional.

2) Pemberian informasi.

3) Partisipasi siswa.

4) Pemberian tes.

5) Tindak lanjut.

Aktivitas preinstruksional memuat tahap motivasi, pemberitahuan tujuan pem-belajaran, dan informasi tentang pengetahuan prasyarat. Pada tahap ini, guru dapat memberikan informasi tentang beberapa hal yang menjadi kesenangan atau minat siswa. Pemberitahuan tujuan dimaksudkan untuk memusatkan strategi belajar siswa dalam mencapai tujuan. Penyampaian tujuan dapat dilakukan secara verbal atau tertulis. Informasi tentang pengetahuan prasyarat dilakukan dengan menunjukkan kemampuan siswa sebelum mengikuti mata pelajaran Agama Islam.

Pemberian informasi menitikberatkan pada isi dan urutan materi dan tahap pembelajaran yang harus dilalui oleh guru dan siswa untuk mencapai tujuan pembelajaran. Pada bagian tersebut, guru menyampaikan informasi kepada siswa disertai dengan pemberian contoh. Penentuan urutan pembelajaran didasarkan atas pertimbangan karakteristik materi yang akan disampaikan oleh guru. misalnya, jika karakteristik materi pembelajaran berupa pemecahan masalah maka urutan penghadiran masalah menjadi prioritas utama. Sebaliknya, apabila materi tersebut berupa pengetahuan deklaratif maka penyampaian informasi menjadi prioritas utama dalam urutan pembelajaran.

Partisipasi siswa dapat diwujudkan dalam bentuk latihan yang dilakukan oleh siswa selama proses pembelajaran. Di samping itu, pemberian balikan (feedback) menjadi bagian penting dalam ikut meningkatkan partisipasi siswa. Kombinasi antara latihan dan balikan menjadi faktor penting dalam menentukan keberhasilan siswa untuk mencapai tujuan pembelajaran.

Pemberian tes sebagai salah satu komponen strategi pembelajaran mempunyai variasi, di antara- nya tes awal, tes pertengahan, dan tes akhir. Tes-tes tersebut sangat penting dilakukan untuk mengontrol pencapaian tujuan pembelajaran, baik pada awal, selama, maupun akhir pembelajaran. Kegiatan ini ditutup dengan memberikan aktivitas lanjutan, seperti pengayaan dan remediasi. Dengan demikian, seluruh komponen strategi pembelajaran mempunyai kaitan erat dalam mengarahkan siswa untuk mencapai tujuan pembelajaran yang telah ditetapkan.

\section{Model Perancangan Pembelajaran}

Dick dan Carey (1990) memaparkan tentang konsep pengajaran, yaitu suatu proses sistematis di mana setiap komponen; guru, siswa, bahan, dan lingkungan pengajaran sangat penting untuk keberhasilan belajar. Setiap komponen itu bekerja secara sistemik untuk mencapai tujuan. Konsep desain sistem instruksional dikemukakan oleh Gagne (1988) sebagai suatu proses perencanaan sistem pengajaran secara sistematis. Konsep lainnya disampaikan oleh Richey (1986) bahwa desain instruksional merupakan ilmu tentang penciptaan spesifikasi-spesifikasi yang rinci untuk pengembangan instruksional.

Prosedur desain instruksional memuat urutan langkah yang harus ditempuh untuk menghasilkan sebuah rancangan pengajaran yang baik. Secara garis besar, Twelker (1972) mengemukakan prosedur perancangan pengajaran yang berawal dari pengidentifikasian, pengembangan, evaluasi dan diakhiri dengan revisi. Oleh karena itu, berikut ini akan diuraikan secara singkat tentang tahapan-tahapan menurut Dick dan Carey (1990).

Urutan-urutan itu menurut Dick dan Carey (1990) dimulai dari identifikasi tujuan pengajaran, melakukan analisis instruksional, mengidentifikasi perilaku dan karakteristik awal siswa, merumuskan tujuan performansi, menyusun atau mengembangkan tes acuan patokan, mengembangkan strategi belajar, mengembangkan atau memilih bahan pengajaran, mengembangkan dan melaksanakan evaluasi formatif, merancang dan melaksanakan evaluasi sumatif, dan diakhiri dengan revisi pengajaran.

\section{Kemampuan Pengelolaan Kelas}

Penjelasan pada bagian ini mengarah kepada dua pembahasan, yaitu kemampuan dan pengelolaan kelas. Dari kedua konsep tersebut dapat membentuk pengertian kemampuan pengelolaan kelas.

Istilah kemampuan identik dengan perolehan belajar yang mengacu pada penguasaan siswa terhadap tujuan pengajaran yang telah ditetapkan. Dilihat dari dimensi psikologis, terutama mengacu kepada pendapat Gagne (1988), hasil belajar dapat 
dipilahkan ke dalam dimensi (1) informasi verbal, (2) kemampuan intelektual, (3) strategi kognitif, (4) sikap, dan (5) kemampuan motorik. Pengelolaan kelas merupakan kemampuan seorang guru dalam merencanakan, mengorganisasikan, dan mengontrol unit terkecil dalam pelaksanaan pembelajaran yang dilakukan secara klasikal (Suharsimi,1988).

\section{Kerangka Berpikir}

Berdasarkan uraian tersebut di atas maka dalam rencana penelitian ini akan dicoba penerapan strategi active learning yang didasarkan pada permasalahanpermasalahan nyata yang berasal dari dunia nyata (kehidupan sehari-hari). Melalui permasalahan nyata kehidupan sehari-hari, siswa menjadi lebih cepat memahami, lebih senang dan berminat karena permasalahan tersebut akrab dengan mereka. Pada akhirnya diharapkan motivasi siswa dapat meningkat sehingga materi yang diberikan lebih terserap secara efektif dan dapat meningkatkan pencapaian kompetensi siswa pada pelajaran Agama Islam .

\section{Hipotesis Tindakan}

Dengan Strategi active learning dapat meningkatkan kompetensi siswa SD Hangtuah V pada pelajaran Agama Islam.

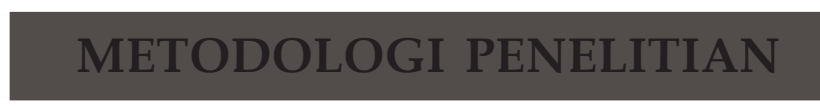

Penelitian ini akan dilaksanakan di kelas II SD Hang Tuah V Jakarta dan dilaksanakan pada semester ganjil tahun akademik 2007/2008. Populasi penelitian ini adalah siswa kelas II A SD Hang Tuah V Jakarta yang mengikuti mata pelajaran Agama Islam pada semester ganjil tahun akademik 2007/2008. Sampel penelitian adalah 30 siswa yang berada dalam satu kelas pembelajaran mata pelajaran Agama Islam.

Metode yang digunakan dalam penelitian ini adalah penelitian tindakan (action research). Adapun tahapan penelitian tindakan adalah sebagai berikut.

1. Tahapan perencanaan, yaitu mengkaji ulang (merenungkan) sistem pembelajaran Agama Islam tahun ajaran yang lalu serta mengembangkan pemikiran tentang strategi pembelajaran active learning dan struktur pengelolaan pembelajarannya dan jenis media belajar yang dapat diterapkan pada pembelajaran Agama Islam melalui pembelajaran active learning. Kajiannya meliputi aspekaspek yang terkait dengan (1) aspek kemampuan mengajar guru, (2) substansi materi yang disampaikan dalam pembelajaran Agama Islam, (3) multimedia yang dapat digunakan untuk mengembangkan pemahaman dan keterampilan mengajar,
(4) strategi pembelajaran active learning, (5) kemampuan pengelolaan kelas, dan (6) sistem penilaian yang digunakan. Setelah permasalahan yang berkaitan dengan proses pembelajaran Agama Islam dapat diiidentifikasi maka dipilih dan ditentukan ber-bagai tindakan yang berkaitan dengan strategi pembelajaran active learning yang mengembangkan hipotesis tindakan sebagai berikut. (1) mengembangkan strategi pembelajaran pada Agama Islam yang diterapkan di SD Hang Tuah V Jakarta, dan (2) menerapkan strategi pembelajaran active learning dalam pembelajaran Agama Islam yang dapat meningkatkan kompetensi dasar siswasiswa SD Hang Tuah V

Jakarta.

2. Tahap tindakan, yaitu menerapkan tindakan berupa strategi pembelajaran active learning dalam pembelajaran Agama Islam. Siklus pertama, pembelajaran menggunakan tahapan pembelajaran berupa (1) review, (2) self-Assessment, (3) future planning, (4) expression of final sentiments, dan (5) perhatian siswa yang disampaikan dengan berbagai teknik pembelajaran antara lain: (1) team building, (2) on-the-spot assessment, (3) immediate learning involvement, (4) full-class learning, (5) class discussion, (6) question prompting, (7) collaborative learning, (8) peer teaching, independent learning, (9) affective learning, dan (10) skill development. Pemilihan tindakan dalam bentuk teknik pembelajaran dilakukan berdasarkan kajian awal pada tahap perencanaan. Siklus kedua dan selanjutnya dilakukan sebagai perbaikan dan penyempurnaan dari tindakan yang dilakukan pada siklus pertama berdasarkan hasil evaluasi.

3. Tahap pengamatan, yaitu melakukan pengamatan kegiatan kelas bersama-sama dengan kolaborator dengan cara mengamati, mencatat, merekam seluruh kegiatan siswa-siswa SD Hang Tuah V Jakarta yang mengikuti Agama Islam. Proses pengumpulan data terfokus pada aspek kemampuan siswa di kelas dan kompetensi dasar yang ingin dicapai dalam Agama Islam. Untuk memudahkan kolaborator dalam mencatat kegiatan pembelajaran Agama Islam maka disediakan lembar observasi. Selanjutnya dilakukan analisis data, baik secara kualitatif maupun kuantitatif. Kegiatan ini dimaksudkan untuk menyeleksi, menyederhanakan, memfokuskan, dan mengorganisasikan data yang berkaitan dengan kemampuan siswa dan kompetensi dasar dalam Agama Islam.

4. Tahap refleksi, yaitu mengevaluasi seberapa jauh dampak penerapan strategi pembelajaran active 
learning dalam pembelajaran Agama Islam pada siklus pertama. Tingkat keberhasilan yang dicapai pada siklus pertama ditunjukkan bahwa sebagian besar siswa (70\%) memiliki keaktifan dalam mengikuti pembelajaran Agama Islam melalui aktivitasaktivitas yang membangun kerja kelompok dan mengelola kegiatan belajar bagi seluruh kelas, kelompok kecil, merangsang diskusi, mempraktikkan keterampilan-keterampilan, mendorong adanya pertanyaan-pertanyaan, dan membuat peserta didik dapat saling belajar satu sama lain. Hasil pengkajian tersebut diperlukan untuk menentukan tindakan selanjutnya yang dikembangkan pada siklus kedua dan ketiga. Bila berhasil pada siklus pertama maka perlu diidentifikasi faktor-faktor tindakan apa yang membuatnya berhasil. Sebaliknya jika mengalami kegagalan harus dicari faktor penyebab mengapa tindakan tersebut belum berhasil. Tindakan yang dilakukan dalam active learning ini dikembangkan sampai pada siklus ke-n sehingga diharapkan setelah siklus ke-n sesuai dengan indikator ketercapaian penelitian yaitu adanya peningkatan kompetensi dasar siswa dalam Agama Islam.

\section{Indikator Kinerja penelitian}

Penelitian tindakan ini dilaksanakan selama dua siklus putaran. Proses berulangnya tindakan dalam setiap siklus ditentukan oleh beberapa ketercapaian indikator kinerja penelitian, antara lain.

a. Sebagian besar siswa $(70 \%)$ memiliki keaktifan dalam mengikuti pembelajaran Agama Islam melalui aktivitas-aktivitas yang membangun kerja kelompok dan mengelola kegiatan belajar bagi seluruh kelas, bagi kelompok kecil, merangsang diskusi, mempraktikkan keterampilan-keterampilan, mendorong adanya pertanyaan-pertanyaan, dan membuat peserta didik dapat saling belajar satu sama lain;

b. Sebagian besar siswa ( $80 \%)$ memiliki kompetensi dasar dalam Agama Islam;

c. Seluruh siswa mencapai nilai lulus dalam pembelajaran Agama Islam ini dan sebagian besar (80\%) mencapai nilai 80; dan

Diperolehnya model pembelajaran Agama Islam yang mengembangkan strategi pembelajaran active learning dalam proses belajar mengajarnya. Hal ini dapat dijadikan sebagai acuan bagi guru-guru di SD Hang Tuah V Jakarta lainnya untuk meningkatkan berbagai strategi pembelajaran yang dapat meningkatkan kualitas pembelajaran di kelas secara lebih terencana sehingga dapat menghasilkan lulusan yang siap berkompetisi.

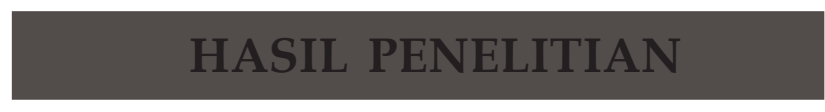

Siklus I

a. Tahap perencanaan

Peneliti mempersiapkan jadwal tindakan siklus I yaitu disesuaikan dengan jadwal mata pelajaran Agama Islam yang diampu oleh anggota peneliti (guru SD) yaitu pada hari Selasa tanggal 25 September 2007, pukul 07.00 - 08.30 di kelas II A di SD Hang Tuah V Jakarta Utara.

Guru mempersiapkan materi yang akan diberikan yaitu berperilaku rendah hati, berperilaku sederhana, hormat kepada orang tua, dan kisah Nabi Adam as dengan menggunakan metode diskusi kelompok. Guru membuat beberapa masalah mengenai topik tersebut. Kemudian membuat kelompok siswa dimana siswa yang berjumlah 30 orang dibagi menjadi lima kelompok dan masing-masing kelompok terdiri dari enam orang.

b. Tahap pelaksanaan

Guru memberikan masalah secara didikte (dictation) mengenai berperilaku rendah hati, berperilaku sederhana, hormat kepada orang tua, dan kisah Nabi Adam AS untuk didiskusikan kepada masingmasing kelompok di mana masalah yang diberikan sama untuk semua kelompok. Masing-masing kelompok mendiskusikan untuk mencari penyelesaian masalah. Peneliti sebagai pengamat mencatat, mengamati, dan memberikan pertanyaan dalam rangka mengumpulkan data (melihat perkembangan yang terjadi selama tindakan diberikan).

c. Tahap evaluasi dan revisi

Evaluasi akhir siklus 1 dilaksanakan pada akhir pembelajaran.

Siklus II

a. Tahap perencanaan

Peneliti mempersiapkan jadwal tindakan siklus II yaitu pada hari Selasa tanggal 2 Oktober 2007, pukul 07.00 - 08.30 di kelas II A di SD Hang Tuah V Jakarta Utara. Guru mempersiapkan materi lanjutan yang akan diberikan, yaitu hal-hal yang berkaitan dengan wudhu dengan menggunakan metode diskusi kelompok ditambah dengan presentasi masingmasing kelompok di depan kelas. Guru membuat beberapa masalah mengenai topik tersebut. Kemudian siswa membuat kelompok yang berjumlah 30 orang dibagi menjadi lima kelompok dan masing-masing kelompok terdiri dari enam orang.

b. Tahap pelaksanaan

Guru memberikan masalah mengenai topik hal-hal 
yang berkaitan dengan wudhu dalam bentuk lem-bar kerja kepada masing-masing kelompok; masalah yang diberikan sama untuk semua kelom-pok. Masing-masing kelompok mendiskusi-kan untuk mencari penyelesaian masalah. Masing-masing kelompok mempresentasikan penyelesaian masalah sedangkan kelompok yang lain menanggapi. Guru beserta siswa menyimpulkan hasil penyelesaian masalah. Peneliti sebagai observer mencatat, mengamati, dan memberikan pertanyaan dalam rangka mengumpulkan data (melihat perkembangan yang terjadi selama tindakan diberikan).

c. Tahap evaluasi dan revisi

Evaluasi akhir siklus II dilaksanakan pada akhir pembelajaran.

\section{Deskripsi Data}

Hasil analisis data untuk kompetensi dasar bidang Agama Islam, strategi pembelajaran active learning dalam Agama Islam di SD Hang Tuah V Jakarta untuk semua siklus adalah sebagai berikut.

1. Data hasil tes kompetensi dasar bidang Agama Islam.

Data hasil nilai rata-rata tes kompetensi dasar bidang agama Islam pada Siklus I berjumlah 67 dan pada Siklus II berjumlah 81.

2. Data strategi active learning.

Data strategi active learning dalam pembelajaran Agama Islam jika dipersentasekan untuk semua siklus tampak pada tabel di bawah ini:

Tabel 1. Hasil Pengamatan Strategi Active Learning

\begin{tabular}{|c|c|c|c|}
\hline \multirow{2}{*}{ No } & \multirow{2}{*}{ Aspek } & \multicolumn{2}{|c|}{ Persentase } \\
\hline & & Siklus I & Siklus II \\
\hline 1 & $\begin{array}{l}\text { Tingkat mobilitas siswa dalam } \\
\text { pembelajaran }\end{array}$ & $65 \%$ & $75 \%$ \\
\hline 2 & Frekuensi bertanya siswa & $70 \%$ & $75 \%$ \\
\hline 3 & $\begin{array}{l}\text { Kemampuan mengungkapkan } \\
\text { informasi }\end{array}$ & $65 \%$ & $80 \%$ \\
\hline 4 & Tingkat interaksi antarsiswa & $60 \%$ & $80 \%$ \\
\hline 5 & Tingkat kerja sama dalam team & $60 \%$ & $80 \%$ \\
\hline 6 & $\begin{array}{l}\text { Tingkat kemandirian dalam } \\
\text { pembelajaran }\end{array}$ & $65 \%$ & $85 \%$ \\
\hline & Rata- Rata & $64 \%$ & $80 \%$ \\
\hline
\end{tabular}

\section{Pembahasan}

\section{Siklus I}

Pada Siklus I nilai rata-rata hasil tes kompetensi siswa SD Hangtuah V pada Agama Islam adalah 67. Artinya ketercapaian kompetensi siswa SD
Hang Tuah V dalam pelajaran Agama Islam baru mencapai $67 \%$. Hal ini disebabkan hasil evaluasi Siklus I belum mencerminkan keberhasilan pelaksanaan penelitian sesuai dengan indikator yang telah ditetapkan yaitu 70\%, maka dilanjutkan dengan Siklus II.

Hasil analisis tentang strategi active learning pada Siklus I masih rendah, yaitu rata-rata baru mencapai $64 \%$ atau pada kisaran skala penilaian 3. Dengan demikian, perlu adanya perbaikan dalam penggunaan strategi active learning pada pembelajaran Agama Islam pada siklus berikutnya.

2. Siklus II

Pada siklus kedua nilai rata-rata hasil tes kompetensi siswa SD Hang Tuah V pada mata pelajaran Agama Islam sudah mencapai 81. Artinya ketercapaian kompetensi siswa sudah mencapai $81 \%$. Ini menunjukkan sudah ada peningkatan sesuai dengan apa yang diharapkan. Hal ini disebabkan hasil evaluasi Siklus II sudah men-cerminkan keberhasilan pelaksanaan penelitian sesuai dengan indikator yang telah ditetapkan, yaitu 70\% maka sudah dianggap cukup bahwa kompetensi siswa sudah meningkat secara signifikan.

Hasil analisis tentang penggunaan strategi active learning pada Siklus II rata-rata sudah mencapai $80 \%$ atau pada kisaran skala penilaian 4 lebih. Ini sudah menunjukkan adanya perbaikan yang cukup signifikan. Dengan demikian, sudah dianggap cukup penggunaan strategi active learning pada pembelajaran Agama Islam dan perlakuan penelitian dihentikan.

Hasil analisis di atas menunjukkan dari Siklus I dan II adanya peningkatan yang cukup signifikan. Dengan demikian, bahwa penggunaan strategi active learning dalam pembelajaran mata kuliah dapat meningkatkan kompetensi siswa SD Hangtuah V dalam pembelajaran Agama Islam.

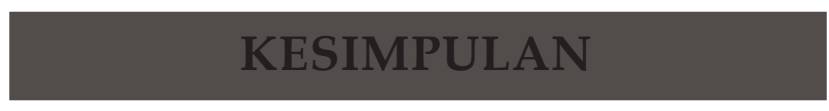

Dari hasil temuan dan analisis di atas maka dapat disimpulkan bahwa penggunaan pendekatan strategi active learning dapat meningkatkan kompetensi siswa SD Hangtuah V pada pelajaran Agama Islam. Implikasi

Dengan hasil penelitian ini yang menunjukkan penggunaan pendekatan strategi active learning dapat meningkatkan kompetensi siswa SD Hangtuah V pada pelajaran Agama Islam maka metode ini dapat dijadikan alternatif dalam setiap pembelajaran terutama dalam pembelajaran Agama Islam. 


\section{Saran}

Berdasarkan kesimpulan hasil penelitian maka disarankan kepada guru pengampu mata pelajaran Agama Islam dan mata pelajaran lain, sebaiknya strategi active learning dapat dijadikan alternatif dalam meningkatkan kompetensi siswa. Lalu, perlu adanya pengkajian mendalam tentang strategi active learning untuk meningkatkan profesionalisme guru dalam pembelajaran Agama Islam. Kemudian, diadakannya penelitian lanjutan untuk selain mata pelajaran Agama Islam.

\section{DAFTAR PUSTAKA}

Dick, W. \& Carey, L. (1990). The systematic design of instruction. Glenview: Scott, Foresman, and Company.

Gagne, R.M., Briggs, L.J., \& Wagner, W.W. (1988). Principles of instructional design. New York: Holt, Rinehart and Winston. Inc.

Kemp, J.E., Morrison, G.R., \& Ross, S.M. (1994). Designing effective instruction. New York: Maxwell Macmillan International.
Richey, R. (1986). The theoretical and conceptual bases of instructional design. New York: Nichols Publishing Company.

Silberman, M. (2001). Active learning. Yogyakarta: Yapendis.

Silberman, Melvin L. (2004). Active learning: 101 cara belajar siswa aktif. Bandung: Nusamedia. Bandung.

Suharsimi, A. (1988). Pengelolaan kelas dan siswa, sebuah pendekatan evaluatif. Jakarta: C.V. Rajawali.

Twelker, P.A., dkk. (1972). The systematic development of instruction:al. Overview and basic guide to the literature. Stanford: The ERIC Clearinghouse on Media and Technology.

\section{KETERANGAN PENULIS}

Syarifah Hanum, lahir di Jakarta 15 Juni 1953, saat ini aktif sebagai dosen Jurusan Pendidikan Guru Sekolah Dasar Fakultas Ilmu Pen-didikan Universitas Negeri Jakarta. 